\title{
DIE SAALSUSTER AS ADMINISTRATEUR
}

\author{
M.S. Potgieter \\ M.Cur. (S.A.) Senior Lektrise, \\ Randse Afrikaanse Universiteit
}

\begin{abstract}
SUMMARY
It is the responsibility of the ward sister at all times to direct her ward as nurse, educationist and administrator. It is further her responsibility to ensure that she is equal to the demands of this great task and that she possesses the necessary knowledge and skill to carry them out effectively.
\end{abstract}

A dministrasie is 'n menslike aktiwiteit wat gemoeid is met die voortbestaan en instandhouding van 'n organisasie en waarin mense saamwerk op 'n georganiseerde wyse om die doelstellings van die organisasie te verwesenlik.

Om te bestuur beteken nie om die werk self te verrig nie, maar om toe te sien dat die personeel hierdie funksies doeltreffend uitvoer. Hierdie verantwoordelikheid vereis leierskap, kennis en die vermoë om selfstandig besluite te kan neem binne die raamwerk van die beleid van die organisasie en daardeur die aktiwiteite te koördineer en te integreer tot 'n eenheid deur middel van beplanning, organisering, motivering en toesighouding.

Verpleegadministrasie in ' $n$ hospitaal is 'n proses waardeur 'n georganiseerde verplegingsdiens sy doelstellings bereik deur middel van mense wat saam werk vir 'n gemeenskaplike doel, nl. 'n omvattende gesondheidsdiens aan al die pasiënte.

Verpleegadministrasie vind op vertikale en horisontale vlakke plaas, met saaladministrasie op die laer vlak van die lyn of op vertikale vlak. Die kwaliteit en kwantiteit van die gehalte verplegingsorg aan die pasiënte sal afhang van die kwaliteit, kennis, vermoëns en verantwoordelikheidsin van die saalsuster.

\section{Wie is die saalsuster?}

Die saalsuster is die bestuurder van 'n eenheid in die operasionele gebied van 'n hospitaal, waar sy direk betrokke is in die versorging van die pasiënte. Sy kan dit nie alleen doen nie, maar tree as leier en as koördineerder van die verplegingspan op wat die funksies verrig.

Die doel van die hospitaal is om aan die behoeftes van die pasiënte te voorsien vir behandeling en rehabilitasie, en in hierdie konteks lê die grootste uitdaging vir die saalsuster.

Die pasiënt kom na die hospitaal as 'n individu; as lid van 'n gesin en die gemeenskap wat 'n behoefte het aan hulp, ondersteuning en begeleiding tot sy herstel. Die belangrikste taak van die saalsuster is om die behoeftes van die pasiënte te bepaal nl. fisies, psigies, geestelik en maatskaplik, en om die versorging van elke pasiënt so te beplan dat aan al sy behoeftes voorsien sal word

Dit is belangrik vir die herstel van die pasiënt dat hy gelukkig en gerieflik binne die perke van sy siekwees sal wees. Die saalsuster kan baie bydra om 'n ontspanne, gemoedelike en terapeutiese omgewing te skep, vry van medies-geregtelike risiko's, of enigiets wat die herstel van die pasiënt kan vertraag.

Die saalsuster is ook ' $n$ belangrike skakel met die mediese, paramediese en huishoudelike personeel, want hulle is almal afhanklik van die inligting wat die saalsuster vir hulle gee vir die uitvoer van hulle pligte sodat al die dienste sinvol vir die pasiënt sal wees. Samewerking, oop kommunikasiekanale en goeie interpersoonlike verhoudinge tussen kollegas en departemente is hoofsaaklik afhanklik van die saalsuster se houding en verantwoordelikheidsin teenoor haar pasiënte, personeel en die hospitaal.

As leier van haar verplegingspan, is dit belangrik dat sy die potensialiteite in haar personeel kan raaksien en dit ontwikkel. Sy moet vertroue in haar personeel hê, lojaal en eerlik teenoor hulle wees, en konsekwent wees in haar optrede. Sy moet 'n hoe moraal en standaard handhaaf en buigbaar wees binne perke wanner nodig, want dan alleen sal daar wedersydse vertroue en goeie samewerking van haar personeel wees.

Dit is belangrik dat elke spanlid moet weet wat van haar verwag word - wat haar pligte en verantwoordelikhede is. Die fisiese omgewing moet gunstig wees vir die bevordering van 'n goeie werksklimaat wat vry van enige gevare en risiko's is.

Sy moet haar personeel die nodige leiding en onderskraging gee en erken as individue met eie behoeftes en verwagtings. Sy moet hulle help om die belangrikheid van hulle bydrae tot die bereiking van die doelstellings van die saal en daardeur die hospitaal, te sien.

\section{Die Rol en Funksies van die Saalsuster}

Ten spyte van die voortdurende veranderinge en verbeteringe in die mediese en tegnologiese wetenskappe, het die saalsuster se rol nog tradisioneel en primêr dieselfde gebly, nl. die versorging van die siekes in al sy dimensies (fisies, psigies, geestelik en maatskaplik). Net die metodes en tegnieke verander gedurig, wat hoë eise aan haar administratiewe kennis en vaardigheid stel in die beplanning van die verpleegsorgprogramme vir elke pasiënt wat in haar sorg is.

Dit is belangrik dat sy kennis dra van die eksterne en interne beleid van die hospitaal, omdat dit as riglyne dien waarbinne sy haar eenheid moet bestuur. Die beleid word saamgevat in die handleidings wat in elke saal behoort te wees. Sy kan dit as verwysingsbronne en as onderrigmedia gebruik, wanneer nodig. Verder moet sy kennis hê van die beginsels van administrasie en haar eenheid daarvolgens bestuur. 


\section{DIE BEGINSELS VAN ADMINISTRASIE}

Verskeie skrywers het dit eens dat daar vier uitstaande beginsels is waarvolgens enige organisasie bestuur moet word, nl. beplanning, organisering, motivering, koördinering en beheer.

\section{Beplanning as 'n bestuurstaak}

Beplanning is die ondersoek na, en keuse tussen alternatiewe weë om die doelwitte te bereik. Bestuur gaan dikwels om veranderinge of afwykings van die daaglikse roetine waar wysigings nodig is en waarvoor beplanning nodig is. Drie vrae kom onmiddellik na vore wanneer ons beplan en waarvoor antwoorde gevind moet word.

1. Wat is ons doelwitte? - d.w.s. waarheen wil ons?

2. Watter middele gaan ons gebruik? - d.w.s. hoe gaan ons kom waar ons wil wees?

3. Hoe gaan ons die waardebepaling doen? nl. - die opweging van doelwitte teenoor die beskikbare middele.

Beplanning is ' $n$ vooruitbepaling van die weg wat gevolg moet word om bepaalde doelwitte te bereik. Dit gaan om die toekoms en behels die optrede van 'n persoon. Dit sluit die bepaling en beplanning van benodighede en personeel in, asook die prosedures en metodes wat gevolg moet word vir die bereiking van die doelwitte.

Wanneer die saalsuster die beplanning vir haar eenheid doen, moet sy eers antwoorde op die volgende vrae vind $\mathrm{nl}$.

- wat gedoen moet word

- wie dit moet doen

- wanneer, waar en hoe dit gedoen moet word

Sy moet die beplanning wetenskaplik benader om sodoende ' $n$ waardebepaling te doen, deur die alternatiewe keuses teen mekaar op te weeg en die beste oplossing te kies vir die bereiking van die doelwitte.

Beplanning staan nie los nie, maar is ineengeweef met organisasie, koördinasie en beheer. Dit is gegrond op die omskrewe doelwitte en dui die standaarde vir evaluering en die rigting wat gevolg moet word, aan.

Die doel van goeie beplanning help die saalsuster:

(i) om konsekwent in haar besluite en optredes te wees;

(ii) help met die integrasie en koördinasie van al die saalaktiwiteite;

(iii) bevorder die ekonomiese gebruik van tyd, personeel en benodighede.

Doelwitte, beleid, prosedures, werksprogramme, skedules, aandienslyste en begroting, is almal planne wat die saalsuster opstel en gebruik dit as raamwerk waarin sy besluite neem om die doelwitte van haar eenheid te verwesenlik. Sy kan nie alleen beplan of besluite neem nie, aangesien sy ' $n$ lid is van die verplegingspan. Sy moet haar spanlede betrek, en hulle pogings inkorporeer en koördineer waar moontlik, sodat alle besluite ' $n$ spanpoging is.

\section{Organisasie as 'n Bestuurstaak}

Organisasie moet doelgerig, doelbewus en doelmatig wees en moet die volgende beklemtoon:

1 'n analise van die behoeftes van elke pasiënt in haar afdeling en die verpleegsorgplanne daarvolgens opgestel;

2 ' $n$ analise van al die ander funksies wat betrokke is by die uitvoer van die planne;

3 delegering van funksies aan die personeel;

4 voorsiening van fisiese hulpbronne;

5 metodes, skedules en prosedure handleidings wat die volgende aandui;

- die funksies wat uitgevoer moet word met die nodige gesag en verantwoordelikheid wat daarmee gepaard gaan;

- beleid, prosedures en beheermaatreels wat duidelik omskryf is;

- diensroosters en pligstate vir die dekking van die saal vir 24 uur per dag met die nodige kategorieë personeel.

In die delegering van take aan die verplegingspan moet sy elkeen se kennis, vermoens en vaardigheid in ag neem vir regverdige verspreiding van die take. Die take moet homogenies gegroepeer word sodat dit meer sinvol is en die personeel instaat stel om optimaal te funksioneer.

Wanneer funksies gedelegeer word in die saalsituasie, gaan dit gepaard met verdeelde verantwoordelikheid, omdat die saalsuster nog die finale verantwoordelikheid dra vir alles wat in haar saal plaasvind. Doeltreffende delegering berus op goeie interpersoonlike verhoudinge en oop kommunikasiekanale tussen die saalsuster en haar spanlede. Dit is belangrik dat sy terugvoer moet ontvang vanaf die personeel aan wie sy die werk gedelegeer het. Dit kan geskied deur direkte kontak of supervisie, of om 'n stelsel vir opvolging daarvan te ontwerp.

'n Bestuurder wat die kuns van delegering verstaan, sal beter samewerking en hoë gehalte werk van haar personeel kry, want sy bied hulle geleenthede om inisiatief te gebruik en besluite te neem. Dit is belangrik dat sy buigbaar moet wees waar nodig en daardeur haar lede saamsnoer in 'n span wat 'n hoë moraal en werkstevredenheid handhaaf en wat saamwerk vir die bereiking van gesamentlike doelwitte.

\section{Koördinasie en Motivering as Bestuurstaak}

Kommunikasie is die basis van koordinasie, aangesien koördinasie daarop gemik is dat almal dieselfde besluite sal neem. Om koordinasie te kry, is motivering van die span nodig veral vir die aanvaarding van die planne, opdragte ensovoorts. Motivering is dus 'n middel tot koördinasie, waar gesag die belangrikste aspek is. Dit word ondersteun deur taakomskrywings, roetine bevele en organisasiegidse wat nodig is om die doelwitte te bereik.

Koördinasie is ' $n$ bindmiddel wat alle funksies tot 'n eenheid bind, en die grootste taak van die saalsuster is. Die terapeutiese span bestaan uit persone van verskillende departemente met wie die saalsuster vertikale en horisontale verhoudinge het, en dit is haar funksie, as leier van die verplegingspan om hierdie funksies te koördineer tot 'n eenheid sodat dit sinvol sal wees.

Motivering is van buitengewone belang vir die sukses van die saalsuster se bestuursvermoë, want sy werk met persone wie se behoeftes verskillend en uiteenlopend is. Sommige mense se behoeftes is om met ander geassosieer te word en erken te word, terwyl ander weer verskil in voorkeure en lojaliteit. Hierdie behoeftes moet in ag geneem word wanneer sy haar personeel motiveer. Sy moet hulle die geleentheid gee om kreatief 
te wees en inisiatief te gebruik in die uitvoer van hulle pligte. Waar lede net instruksies ontvang en vir hulle besluite geneem word sal misverstande algemeen voorkom sowel as 'n lae werksmoraal. Dit is belangrik dat die saalsuster haar personeel raadpleeg en hulle laat deelneem aan besluitneming want dan sal hulle gemotiveerd wees en 'n hoë moraal en werkstevredenheid handhaaf. Hulle sal ook bereid wees om meer as hulle kant te bring.

\section{Beheer as 'n Bestuurstaak}

Die leiding wat die saalsuster vir haar personeel gee is vir doelgerigte werking. Vanweë die inherente tekortkominge en gebreke van mense en goedere moet sy toesig hou oor die personeel om te verseker dat die werklike prestasie in ooreenstemming is met wat beplan is.

Beheer is die reëlende taak van leiding, dit meet die werkverrigtinge van die saal en is ' $n$ belangrike gids by die uitvoering van die planne. Dit dui aan waar van die planne afgewyk is, sodat stappe tot herstel en voorkoming yan herhaling geneem kan word.

Die beheertaak is ineengeweef met beplanning, organisasie en koördinasie. Daar moet immers voorafbeplande standaarde wees waraan die werklikheid gemeet kan word met metodes vir evaluering. Beheer veronderstel dus die reg om opdragte te gee, te adviseer, sanksies te gebruik en optrede te wysig, wat nie effektief kan geskied sonder om die bestuursbeginsels deurgaans toe te pas nie.

Die suster moet die volgende stappe in beheer volg as sy die kwaliteit van haar bestuursvermoë wil evalueer $\mathrm{nl}$.

1 Sy moet standaarde stel by strategiese punte wat verbind word aan individuele verantwoordelikhede om verspilling van tyd, geld, mannekrag en hulpbronne te voorkom.

2 Waarneming en verslagdoening van die werklike prestasie teenoor die standaarde te meet.

3 Afwykings moet beoordeel word en verslag daaroor doen.

4 Korrektiewe maatreëls neem vir remediëring, of daarop te verbeter en te verhoed dat soortgelyke toestande in die toekoms sal ontstaan.

Beheer is 'n sirkelproses met terugkoppeling deur taakstelling, kommunikasie en kontinue korreksie, en in 'n sekere sin die siel van beplanning en koördinasie. Beheer impliseer dat.daar doelwitte, planne, beleid en roetine bevele is, wat afhang van hulle diensbaarheid vir die bereiking van die doelwitte.

Beheer moet gedurig aanpas by die veranderde en veranderende omstandighede om alle hindernisse uit die weg te ruim. Dit is belangrik dat dit buigbaar is waar nodig, en nie onwrikbaar by die vooropgestelde standaarde hou nie.

\section{Beheermaatreëls wat deur die saalsuster toegepas kan word:}

1 Waarneming d.m.v. saalrondtes wat sistematies en doelgerig moet wees.

2 Hersiening van die bestaande prosedures en riglyne wat ondoeltreffend blyk te wees.

3 Oudit van die pasiëntverslae om te verseker dat alle waarnemings en behandelinge, soos voorgeskryf, noukeurig uitgevoer is.
4 Die voorbeeld wat sy stel wat op haar lewens-enwerksfilosofie berus.

5 Staande reèls, opdragte en prosedures soos roetine instruksies wat as riglyne dien.

6 Kontrole oor uitgawes, tyd en die gebruik van hulpmiddele.

7 Kontrole en instandhouding van voorrade, toerusting, linne ensovoorts.

8 beheer oor:

- waardevolle artikels en besittings van pasiënte en die hospitaal;

- geskeduleerde medisyne en die toediening daarvan;

- personeel t.o.v. veiligheid van die pasiënte en die personeel self.

9 Dissiplinêre maatreëls wat positief moet wees d.m.v. leiding, motivering en onderrig. Waar negatiewe maatreëls nodig blyk te wees d.m.v. afkeuring en berisping.

Spesifieke en roetine administratiewe pligte van 'n saalsuster

Aangesien die saalsuster die spil is waarom alles draai en verantwoordelik is teenoor die matrone, die superintendent, die geneesheer, die pasiënte en die gemeenskap vir die kwalitatiewe en kwantitatiewe verpleegsorg wat gehandhaaf word in haar saal, bly sy ook nog verantwoordelik vir die volgende:

1 Jaarlikse begroting van benodighede vir haar saal in die vorm van toerusting en instandhouding of herbeplanning van die fisiese opset van haar saal.

2 Beheer van infeksie m.b.t. hantering van besoedelde en besmette linne en toerusting.

3 Die bestel, beheer en toediening van geskeduleerde geneesmiddels.

4 Kontrole oor die bestel van voorrade en die voorkoming van ophoping of wangebruik daarvan.

5 Kontrole oor die bestel van dieëte en kruideniersware.

6 Instandhouding van die fisiese omgewing.

7 Toesighouding oor die sindelikheid van haar saal en die skoonmaakspan.

8 Voorsiening van toerusting, voorrade en hulpmiddels wat die personeel nodig mag kry in die uitvoer van hulle daaglikse pligte.

9 Verkryging van monsters en die versending daarvan.

10 Toe te sien dat pasiëntrekords volledig en korrek gehou word en dat alle verslae soos X-strale en laboratoriumreporte so gou moontlik ontvang en geliaseer word.

11 Sy moet toesien dat een van die personeellede die geneeshere op hulle rondtes vergesel en die korrekte inligting aan hulle gee omtrent die behandeling en vordering van die pasiënte.

Alles wat die geneeshere op hulle rondtes mag benodig moet byderhand en beskikbaar wees.

12 Goeie verhoudinge moet gehandhaaf word met die terapeutiese span en ander departemente wat bydra tot die versorging en herstel van haar pasiënte.

Ten slotte is dit die verantwoordelikheid van die saalsuster om ten alle tye haar saal te bestuur as 
verpleegkundige, opvoedkundige en bestuurder. Dit is haar verantwoordelikheid om toe te sien dat sy opgewasse is vir hierdie groot taak en dat sy die nodige kennis en vaardigheid het om hierdie taak doeltreffend uit te voer.
Bibliografie

1. Alexander, E.: Nursing Administration. 2de uitgawe. C.V. Mosby Co., Saint Louis 1978

2. Di Vincenti, M.: Administering Nursing Service. 2de Uitgawe. Little, Brown \& Co. Boston.

3. Drucker, P.F.: The Practice of Management. Pan Books, William Heinemann. New York. 9de Uitgawe 1977

4. Perry, E.L.: W'ard Administration and teaching. Bailliere, Tindall \& Cassell L.d. Lon don W.C. 21970

Reynders, H.J.J.: Die Taak van die Bedryfsleier. 3de Uitgawe. JL Van Schaik Pretoria. 1975 